UDC 544.344.015.3: 546.57'23

\title{
Ag-Sn-Se SYSTEM: PHASE DIAGRAM, THERMODYNAMICS AND MODELING
}

\author{
F.S.Ibrahimova \\ M.Nagiyev Institute of Catalysis and Inorganic Chemistry, NAS of Azerbaijan
}

ifs@live.ru

Received 24.06.2019

\begin{abstract}
A comparative analysis of works on the study of phase equilibria, structures and thermodynamic properties of intermediate phases of the $\mathrm{Ag}-\mathrm{Sn}-\mathrm{Se}$ ternary system has been carried out. It was shown that two ternary compounds $\mathrm{Ag}_{8} \mathrm{SnSe}_{6}$ and $\mathrm{AgSnSe}_{2}$ are formed in the system, melting congruently at $1015 \mathrm{~K}$ and incongruently at $860 \mathrm{~K}$, respectively. The most reliable data for enthalpy, entropy, free formation energy, and heat capacities of $\mathrm{AgSnSe}_{2}$ and the argirodit phase of $\mathrm{Ag}_{8} \mathrm{SnSe}_{6}$ are recommended. Thermodynamic functions of mixing liquid solutions are approximated by an asymmetric version of the model of regular solutions. To determine the boundaries of the separation of liquid alloys, the function of the internal thermodynamic stability of the homogeneous phase was used. With the help of the program OriginLab, multi 3D visualization of $\mathrm{Ag}_{2} \mathrm{Se}, \mathrm{SnSe}_{2}, \mathrm{SnSe}, \mathrm{Ag}_{8} \mathrm{SnSe}_{6}$ crystallization surfaces and immiscibility surfaces in the $\mathrm{Ag}-\mathrm{Sn}-\mathrm{Se}$ system was carried out.
\end{abstract}

Keywords: copper-lead-tellurium system, phase diagram, the surface of the liquidus, 3D modeling.

doi

\section{Introduction}

The growing interest to the $\mathrm{Ag}-\mathrm{Sn}-\mathrm{Se}$ system is due to the fact that silver-tin selenides, in particular the $\mathrm{Ag}_{8} \mathrm{SnSe}_{6}$ compound, and other representatives of natural minerals Argyrodites have mixed ionic-electronic conductivity in combination with high thermoelectric and optical properties, superconductivity [1-3]. Therefore, silver-tin selenides are promising materials for use in photo-electrodes, electrochemical converters of solar energy, ion-selective sensors, photoelectrochemical vi-sualizations [4-8]. The phase equilibria in the $\mathrm{Ag}-\mathrm{Sn}-\mathrm{Se}$ system have been investigated in a number of papers [9-15]. However, the results of these studies on phase equilibria and thermodynamic parameters are often different. In recent years, work has appeared on 3D modeling of mono- and non-invariant equilibria in this system. The purpose of this review is to analyze and systematize the works on the study of phase diagrams, structures and thermodynamic properties of intermediate phases of the $\mathrm{Ag}-$ Sn-Se ternary system.

\section{Phase diagram and properties of ternary compounds}

The phase diagrams of this system were first studied in [9] with the construction of the $\mathrm{Ag}_{2} \mathrm{Se}-\mathrm{SnSe}_{2}$ quasi-binary cross section state diagram. It was shown that a single ternary compound $\mathrm{Ag}_{8} \mathrm{SnSe}_{6}$ with incongruent melting at $1008 \mathrm{~K}$ and a polymorphic transition at $356 \mathrm{~K}$ is formed in this section. However, in [10], the $\mathrm{Ag}_{2} \mathrm{Se}-\mathrm{SnSe}_{2}$ cut is not vasibinary, and the $\mathrm{Ag}_{8} \mathrm{SnSe}_{6}$ compound melts congruently at $1027 \mathrm{~K}$ a later published paper [11] reported on the synthesis of a compound $\mathrm{Ag}_{2} \mathrm{SnSe}_{3}$. The $\mathrm{Ag}_{2} \mathrm{Se}-\mathrm{SnSe}$ cross section was studied in [12$15]$. According to $[12,14,15]$, this section is quasi-binary and belongs to the eutectic type: the crystallization temperatures of the eutectic are 824,818 and $883 \mathrm{~K}$, respectively. In [13], it is reported that the $\mathrm{Ag}_{2} \mathrm{Se}-\mathrm{SnSe}$ cut is not quasi-binary due to the presence of a field of primary crystallization of free silver. A complete diagram of the $\mathrm{Ag}-\mathrm{Sn}-\mathrm{Se}$ system is presented in [10] with the determination of the liquidus surface, on which the ternary compounds $\mathrm{Ag}_{8} \mathrm{SnSe}_{6}$ and $\mathrm{AgSnSe}_{2}$ and two immiscibility areas are reflected. In [13], the phase equilibrium picture in the region of $\mathrm{Ag}-\mathrm{Ag}_{2} \mathrm{Se}-$ $\mathrm{Ag}_{8} \mathrm{SnSe}_{6}-\mathrm{SnSe}-\mathrm{Sn}$ composition is slightly different from [10]. In [13], a somewhat different form of phase equilibria from [10] is presented in the region of $\mathrm{Ag}-\mathrm{Ag}_{2} \mathrm{Se}-\mathrm{Ag}_{8} \mathrm{SnSe}_{6}-\mathrm{SnSe}-\mathrm{Sn}$ compositions. According to the analysis of [13] and [15], in the state diagram constructed in [10] 5 monovariant phase equilibria converge at two nonvariant points, which contradicts the phase rule, and there is a field on the liquidus surface projection that cannot be attributed to the primary crystallization phase system. 
The crystallographic data of the ternary compounds $\mathrm{Ag}_{8} \mathrm{SnSe}_{6}$ and $\mathrm{AgSnSe} \mathrm{S}_{2}$ are presented in [1, 14-17]. The high-temperature modification of $\mathrm{Ag}_{8} \mathrm{SnSe}_{6}$ crystallizes in a cubic lattice (space group $F-43 m$ ) with a period $a=1.112 \mathrm{~nm}$ [14], and low-temperature in an orthorhombic (space group $P m n 2_{1}$ ) with parameters $a=$ $0.79168(6), b=0.78219(6), c=1.10453(8) \mathrm{nm}$ [16]. The phase of variable composition based on $\mathrm{AgSnSe}_{2}$ has a cubic structure of the $\mathrm{NaCl}$ type, the lattice period for the stoichiometric composition is $a=0.5627 \mathrm{~nm}$ [17].

Due to the inconsistency of literature data on phase equilibria in the Ag-Sn-Se system, the phase diagram was thoroughly studied in [15]. In this work, based on the study of the phase diagrams quasibinary sections $\mathrm{Ag}_{2} \mathrm{Se}-$ $\mathrm{SnSe}_{2}, \quad \mathrm{Ag}_{2} \mathrm{Se}-\mathrm{SnSe}, \quad \mathrm{Ag}_{8} \mathrm{SnSe}_{6}-\mathrm{SnSe}$,
$\mathrm{Ag}_{8} \mathrm{SnSe}_{6}-\mathrm{Se}$ and polytermic incisions $\mathrm{AgSe}-$ SnSe, $\mathrm{Ag}_{2} \mathrm{Se}-3 \mathrm{Sn} \mathrm{Ag}-\mathrm{SnSe}, \mathrm{AgSn}-\mathrm{Se}$ received new refined phase diagram system

$\mathrm{Ag}-\mathrm{Sn}-\mathrm{Se}$ (Figure 1, 2), somewhat different from those previously given in the literature. It was shown that two ternary compounds $\mathrm{Ag}_{8} \mathrm{SnSe}_{6}$ and $\mathrm{AgSnSe}_{2}$ are formed in the system, melting congruently at $1015 \mathrm{~K}$ and incongruently at $860 \mathrm{~K}$, respectively. Earlier in the above literature ternary compound $\mathrm{Ag}_{2} \mathrm{SnSe}_{3}$ not confirmed. Based on the phase diagrams of the boundary binary systems using a limited number of DTA data, 3D modeling and visualization of the liquidus surfaces and immiscibility in the $\mathrm{Ag}-\mathrm{Sn}-\mathrm{Se}$ ternary system was carried out. For the calculation and 3D modeling, the analytical method proposed and tested in [1820] was used.

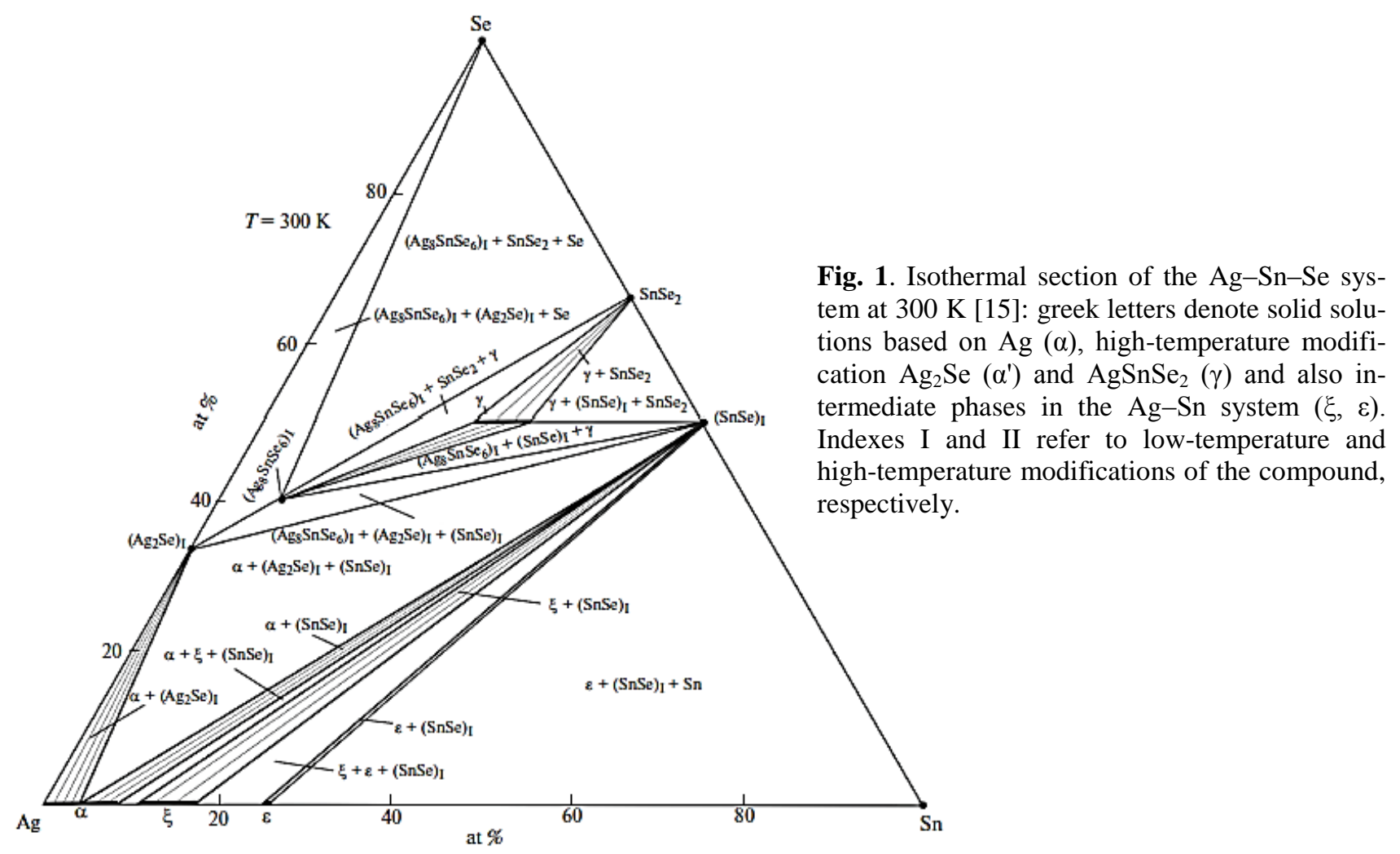




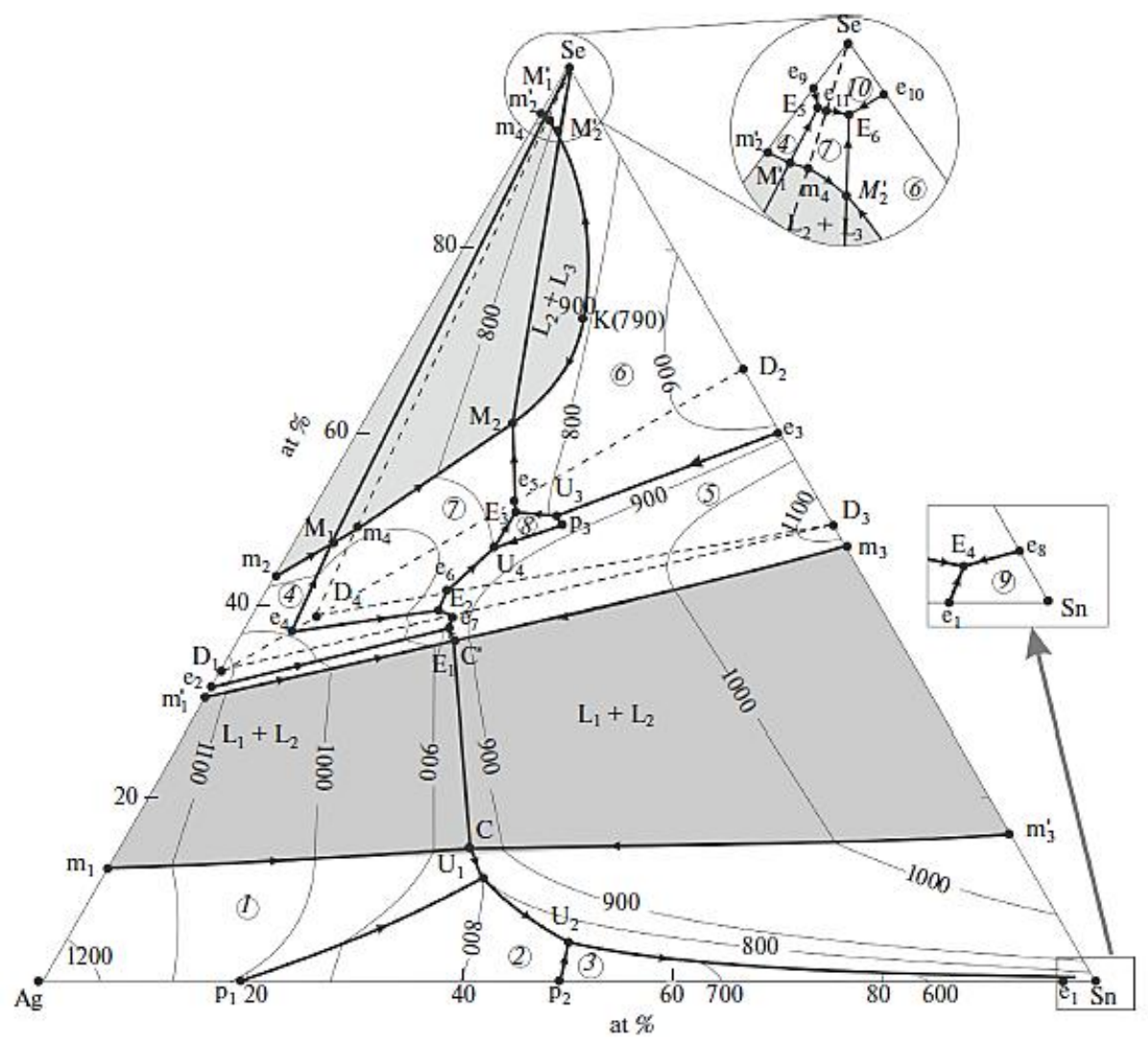

Fig. 2. Projection of the liquidus surface and immiscibility in the Ag-Sn-Se system [15]. Primary crystallization fields: 1 -solid solutions based on $\mathrm{Ag}$; 2,3-intermediate phases in the $\mathrm{Ag}-\mathrm{Sn}$ system; 4 - high temperature modification of $\mathrm{Ag}_{2} \mathrm{Se} ; 5-\mathrm{SnSe}$ (I, II); $6-\mathrm{SnSe}_{2} ; 7-\mathrm{Ag}_{8} \mathrm{SnSe}_{6}$ (II); $8-$ $\mathrm{AgSnSe}_{2} ; 9$ - Sn; 10 - Se. Indexes I and II refer to low-temperature and high-temperature modifications of the compound, respectively.

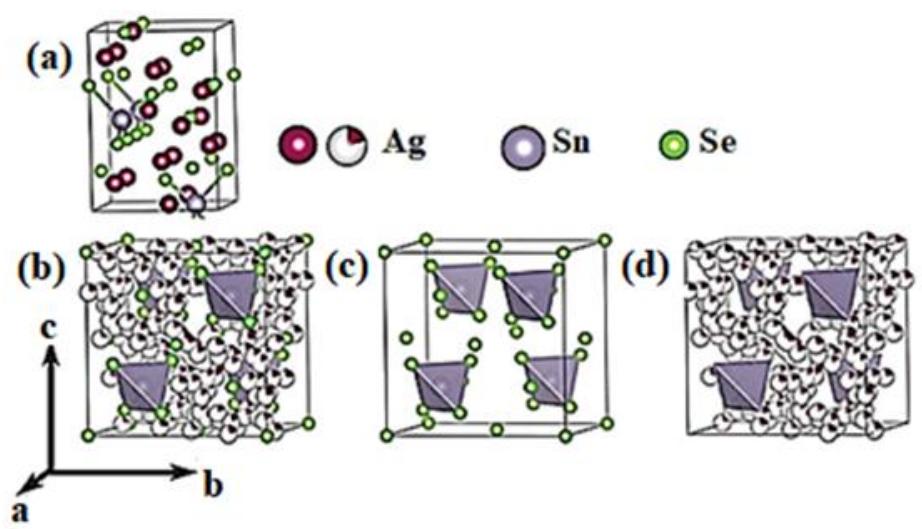

Fig. 3. The orthorhombic structure of $\beta-\mathrm{Ag}_{8} \mathrm{SnSe}_{6}$ with the space group $P m n 2_{1}(a)$. The cubic structure of $\gamma-\mathrm{Ag}_{8} \mathrm{SnSe}_{6}$ with the space group $F \overline{4} 3 \mathrm{~m}$. (b). The cubic structure can be considered as $\mathrm{Se}^{2-}$ anions forming a cubic frame with four $\mathrm{Se}^{2-}$ and four tetrahedral $\left[\mathrm{SnSe}_{4}\right]^{4-}$ units inside the tetrahedral voids $(c) \mathrm{Ag}^{+}$ions are delocalized over the entire cubic structure. Green spheres indicate selenium, medium violet indicates tin, and fully filled and partially filled red spheres indicate $\operatorname{Ag}^{+}(d)$. 
In [1], using the sintering technology in a hot press, a $\gamma$ - $\mathrm{Ag}_{8} \mathrm{SnSe}_{6}-n$-type superionic semiconductor compound was synthesized, which is a promising thermoelectric material up to $550^{\circ} \mathrm{C}$. It was revealed that $\beta-\mathrm{Ag}_{8} \mathrm{SnSe}_{6}$ has an orthorhombic structure with the space group $P m n 2_{1}$ and is not a superionic conductor (Figure $3 a$ ). At the same time, the $\gamma$-phase with superionic conductivity has a face-centered cubic structure with a space group of $F \overline{4} 3 m$ (Figure $3 b$ ).

It was also found in [1] that the $\beta \leftrightarrow \gamma$ structural transition occurs between $80^{\circ} \mathrm{C}$ and $90^{\circ} \mathrm{C}$ (Figure 4).

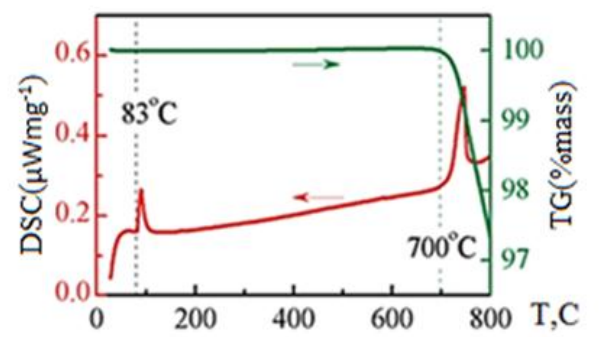

Fig. 4. TG-DSC curves showing the $\beta \leftrightarrow \gamma$ phase transition at $83^{\circ} \mathrm{C}$ and melting/decomposition at $700^{\circ} \mathrm{C}$ [1].

\section{Thermodynamics}

In [1] it was revealed that the thermal conductivity of the $\gamma$-phase $\mathrm{Ag}_{8} \mathrm{SnSe}_{6}$ at temperatures above is below the glass limit, for the reason that the heat capacity $\mathrm{C}_{V}$ and $\mathrm{C}_{\mathrm{p}}$ is less than $3 \mathrm{Nk}_{\mathrm{B}}\left(\mathrm{N}\right.$ is Avogadro number and $\mathrm{k}_{\mathrm{B}}$ is Boltzmann constant) and this phase has ultralow thermal diffusion coefficient (Figure 5).

From Figure $5 b$ it follows that $\mathrm{C}_{\mathrm{p}}=\mathrm{C}_{\mathrm{v}}$. At analyzing the data in Figure $5 \mathrm{~b}$, the question arose about the dimension $\mathrm{C}_{\mathrm{p}}\left(\mathrm{C}_{\mathrm{v}}\right)$ on the ordinate. According to the Dyulong-Petit formula for one mol-atom of the compound $\mathrm{C}_{\mathrm{p}}=3 N_{\mathrm{A}} k_{\mathrm{B}}$ $=24.96 \mathrm{~J} /(\mathrm{mol} \text {-atom } \mathrm{K})^{-1}$. This indicates that the values of heat capacity on the ordinate of Figure $5 b$ refer to one mole-atom of the $\mathrm{Ag}_{8} \mathrm{SnSe}_{6}$ compound and are presented in $C_{p} \cdot 10^{-2}$. Then from the graph in Figure $5 b$ for $T=298 \mathrm{~K}$ we can write $C_{p, 298}\left(\mathrm{Ag}_{8} \mathrm{SnSe}_{6}\right)=0.26 \cdot 100 \cdot 15=390$ $\mathrm{J} \cdot \mathrm{mol}^{-1} \cdot \mathrm{K}^{-1}$. Here 15 is the number of atoms in the $\mathrm{Ag}_{8} \mathrm{SnSe}_{6}$ molecule. According to the Dyulong-Petit $C_{p, 298}\left(\mathrm{Ag}_{8} \mathrm{SnSe}_{6}\right)=374 \mathrm{~J} \cdot \mathrm{mol}^{-1} \cdot \mathrm{K}^{-1}$. The molar heat capacity of $\mathrm{Ag}_{8} \mathrm{SnSe}_{6}$ was also calculated using the methods of Kubashevsky and Ivanova, previously successfully tested in [21-25]. When applied to the $\mathrm{Ag}_{8} \mathrm{SnSe}_{6}$ compound, the Ivanova equation [23] has the form:

$$
C_{p, 298}\left(\mathrm{Ag}_{8} \mathrm{SnSe}_{6}\right)=m\left(22.14+2480 / T_{\mathrm{m}}\right)
$$

$m=15, T_{\mathrm{m}}\left(\mathrm{Ag}_{8} \mathrm{SnSe}_{6}\right)=1015 \mathrm{~K}$ [5]. Then from (1) it follows that $C_{p, 298}\left(\mathrm{Ag}_{8} \mathrm{SnSe}_{6}\right)=368.7$.

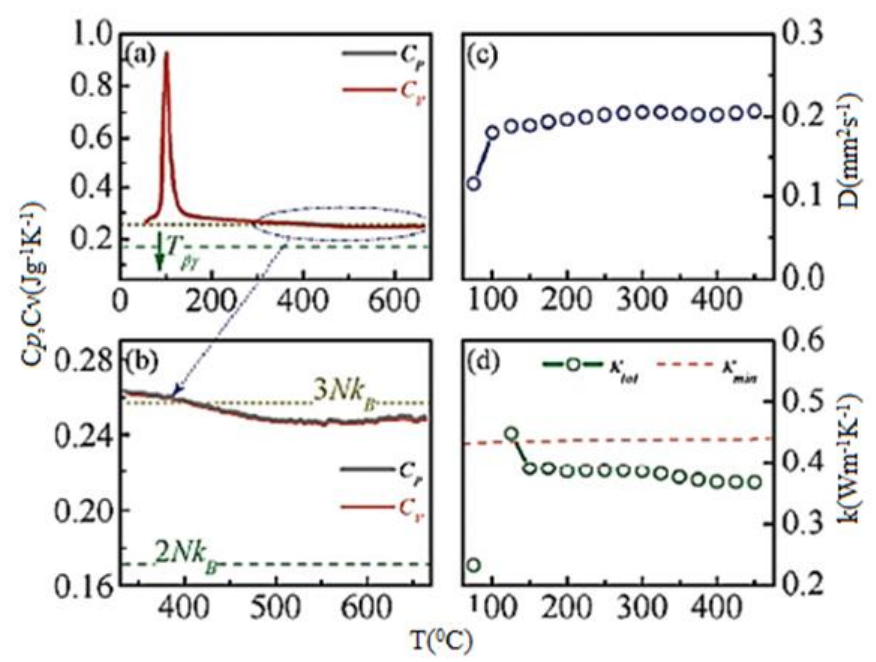

Fig. 5. Data for $\gamma-\mathrm{Ag}_{8} \mathrm{SnSe}_{6}$ [1]: (a) $C_{P}(T)$ and $C_{V}(T)$ dependences. Data for high $T$, for clarity, is given in $(b)$. The dashed dark yellow line and the dashed green line indicate the Dulong-Petit limit for $C_{p}$ and the lowest theoretical $C_{\mathrm{p}}$ value, respectively. In $(c)$, the diffusion coefficient $\mathrm{D}$ is shown as a function of temperature, and the total thermal conductivity $\left(k_{\mathrm{tot}}\right)$ and the maximum thermal conductivity of the crystal lattice $\left(k_{\min }\right)$ are presented in the graph $(d)$. 
It follows from the calculations that, on the one hand, the dimension of the heat capacity on the ordinate in Figure $5 b$ is indicated incorrectly; on the other hand, the experimental values of the heat capacity of $\mathrm{Ag}_{8} \mathrm{SnSe}_{6}$ obtained in [1] are reliable. The thermodynamic data of silver, tin, and ternary selenides are systematized in Table 1.

In binary side systems $\mathrm{Ag}-\mathrm{Se}$ and $\mathrm{Sn}-\mathrm{Se}$ of the ternary system $\mathrm{Ag}-\mathrm{Sn}-\mathrm{Se}$, there are wide areas of homogeneity that propagate inside the concentration (Figure 2) triangle. For the calculation and approximation of the free energy of mixing liquid solutions, an asymmetric version of the model of regular solutions, successfully tested in [35-38], was used:

$\Delta G_{T}^{0}=\left[\mathrm{a}+\mathrm{b}(1-x)^{2}\right](1-x) x+\mathrm{RT}[x \ln x+(1-x) \ln (1-x)],(2)$

where $\Delta G_{T}^{0}-$ free energy of mixing of liquid solutions, the first term-entropy of mixing liquid solutions, the second term-entropy of mixing, $R=8.314 \mathrm{Jmol}^{-1} \cdot \mathrm{K}^{-1}$ ).

Equation (1) is solved on the basis of the Baevsky Bayesian approximation [39]. To deter- mine the immiscibility boundary, the thermodynamic condition of internal stability is used:

$$
\left(\partial^{2} \Delta G^{0} / \partial x^{2}\right)_{P, T}>0[40] .
$$

The second derivative of the Gibbs free energy (2) is defined as follows.

$\left(\partial^{2} \Delta \mathrm{G}^{0} / \partial \mathrm{x}^{2}\right)_{\mathrm{P}, \mathrm{T}}=-2 \cdot\left(a+b \cdot x^{2}+2 \cdot b \cdot x \cdot(x-1)+b \cdot x \cdot(3 \cdot x-1)\right)+$ $8.31 \cdot \mathrm{T} /(1-x)+8.31 \cdot T / x$

The second derivative is determined using the online program [46]. The dependences of the function (3) for temperatures of 900, 950, 1000,1050 , and $1080 \mathrm{~K}$ are shown in Figure 6.

As a result of thermodynamic calculations, it was revealed that the critical solubility temperature in the $\mathrm{Ag}-\mathrm{Se}$ system is equal to $T=1080 \mathrm{~K}$. In this temperature in the concentration range $X_{\mathrm{Se}}=$ $0.45 \div 0.95$, the function of internal stability is greater than zero $\left(\partial^{2} \Delta G^{0} / \partial x^{2}\right)_{P, T}>0$. The dependence of the temperature for the separation boundary on the composition is approximated by the equation

$T, \mathrm{~K}=-6887.39418+42972.06249 x-87204.80219 x^{2}+$ $+79466.09268 x^{3}-27593.75741 x^{4}$

Standard thermodynamic functions of silver, tin and ternary selenides

\begin{tabular}{|c|c|c|c|c|c|}
\hline Phase & $\begin{array}{c}-\Delta \mathrm{G}_{\mathrm{f}}^{\frac{0}{\mathrm{f}}}, 298 \\
\mathrm{~kJ} / \mathrm{mol}\end{array}$ & $\begin{array}{c}-\Delta \mathrm{H}_{\mathrm{f}}^{\frac{0}{2}}, 298 \\
\mathrm{~kJ} / \mathrm{mol}\end{array}$ & $\begin{array}{l}\Delta \mathrm{S}_{\mathrm{f}}^{\frac{0}{\mathrm{f}}}, 298 \\
\mathrm{~J} /(\mathrm{mol} . \mathrm{K})\end{array}$ & $\begin{array}{l}\mathrm{C}_{p}^{\frac{0}{p}}, 298 \\
\mathrm{~J} /(\text { mol.K })\end{array}$ & Source \\
\hline$\gamma-\mathrm{Ag}_{8} \mathrm{SnSe}_{6},{ }^{*}$ & $352.5 \pm 1.9$ & $323.1 \pm 1.6$ & $98.6 \pm 3.1$ & $378.5 \pm 3.5$ & $\begin{array}{c}{[25,26]} \\
{[1]}\end{array}$ \\
\hline $\mathrm{AgSnSe}_{2}$ & $133.9 \pm 1.6$ & $124.9 \pm 1.3$ & $30.1 \pm 2.5$ & & {$[25,26]$} \\
\hline$\beta-\mathrm{Ag}_{2} \mathrm{Se}$ & $59.3 \pm 0.6$ & $51.9 \pm 0.5$ & $25.1 \pm 0.9$ & $81.75 \pm 0.42$ & $\begin{array}{l}{[25,26]} \\
{[27,28]}\end{array}$ \\
\hline $\mathrm{SnSe}$ & $90.3 \pm 1.9$ & $77.8 \pm 1.7$ & $42.3 \pm 3.2$ & $49.06 \pm 0.5$ & $\begin{array}{l}{[25]} \\
{[29]}\end{array}$ \\
\hline $\mathrm{SnSe}$ & $96.3 \pm 0.4$ & $94.6 \pm 2.1$ & $5.0 \pm 1.6$ & & [24] \\
\hline $\mathrm{SnSe}_{2}$ & $77.3 \pm 2.5$ & $82.4 \pm 4.5$ & $-17.2+2.5$ & $\begin{array}{l}76.7 \pm 5 \\
73.39 \pm 0.8\end{array}$ & $\begin{array}{l}{[24]} \\
{[29]}\end{array}$ \\
\hline $\mathrm{AgSnSe}_{2}$ & $146.4 \pm 0.5$ & $148 \pm 3$ & $-5.37 \pm 1.5$ & & {$[30,31]$} \\
\hline$\gamma-\mathrm{Ag}_{8} \mathrm{SnSe}_{6}$ & $350.3 \pm 1.8$ & $320.4 \pm 8.1$ & $100.35 \pm 8.5$ & & {$[30,31]$} \\
\hline$\beta-\mathrm{Ag}_{2} \mathrm{Se}$ & $47.6 \pm 1.5$ & $35.0 \pm 2.5$ & $42.21 \pm 0.5$ & & [32] \\
\hline$\beta-\mathrm{Ag}_{2} \mathrm{Se}$ & $47.6 \pm 0.1$ & $35.1 \pm 0.1$ & $42.18 \pm 0.2$ & & $408-500 \mathrm{~K}$ [33] \\
\hline
\end{tabular}

$\gamma-\mathrm{Ag}_{8} \mathrm{SnSe}_{6}, *-$ thermodynamic functions of this phase are determined by extrapolation of the EMF data measured in the interval $480-560 \mathrm{~K}$. 


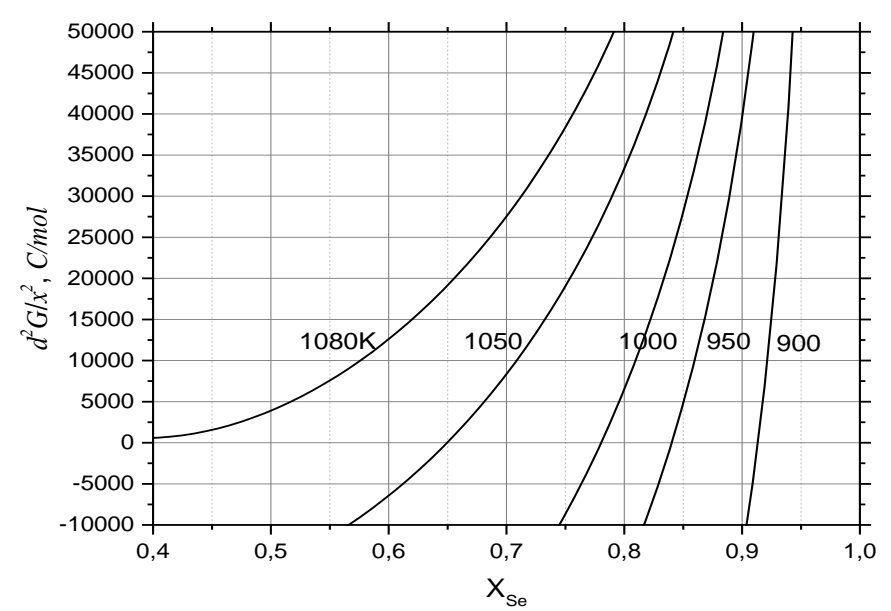

Fig. 6. The dependence of the internal stability function of Gibbs on the mole fraction of selenium for liquid alloys of the $\mathrm{Ag}-\mathrm{Se}$ system in the composition range $\mathrm{xSe}=0.45 \div 0.95$. (All functions are presented in the version for computer programs):

$-2 \cdot\left(16000-10000 \cdot x^{2}-2 \cdot 10000 \cdot x \cdot(x-1)-10000 \cdot x \cdot(3 \cdot x-1)\right)+8.31 \cdot 1080 /(1-x)+8.31 \cdot 1080 / x$

$-2 \cdot\left(25000-10000 \cdot x^{2}-2 \cdot 10000 \cdot x \cdot(x-1)-10000 \cdot x \cdot(3 \cdot x-1)\right)+8.31 \cdot 1050 /(1-x)+8.31 \cdot 1050 / x$

$-2 \cdot\left(40000-12000 \cdot x^{2}-2 \cdot 12000 \cdot x \cdot(x-1)-12000 \cdot x \cdot(3 \cdot x-1)\right)+8.31 \cdot 1000 /(1-x)+8.31 \cdot 1000 / x$

$-2 \cdot\left(50000-12000 \cdot x^{2}-2 \cdot 12000 \cdot x \cdot(x-1)-12000 \cdot x \cdot(3 \cdot x-1)\right)+8.31 \cdot 950 /(1-x)+8.31 \cdot 950 / x$

$-2 \cdot\left(70000-10000 \cdot x^{2}-2 \cdot 10000 \cdot x \cdot(x-1)-10000 \cdot x \cdot(3 \cdot x-1)\right)+8.31 \cdot 900 /(1-x)+8.31 \cdot 900 / x$

Similar equations were obtained for other phase regions and used for analytical 3D modeling of the crystallization surface and separation of liquid solutions of the $\mathrm{Ag}-\mathrm{Sn}-\mathrm{Se}$ system (Figure 7).

\section{Modeling}

The use of a genetic algorithm with Bayesian statistics makes it possible to efficiently and meaningfully combine uncertain data sets, both large and small [39]. This process then leads to the optimization of the parameters of the proposed models and the assessment of the overall forecast confidence in these models. In particular, this work determines the degree of uncertainty at the interphase boundaries of the crystallization surface of $\mathrm{SnSe}, \mathrm{SnSe}_{2}, \mathrm{Ag}_{2} \mathrm{Se}, \mathrm{Ag}_{8} \mathrm{SnSe}_{6}$ compounds in the $\mathrm{Ag}-\mathrm{Sn}-\mathrm{Se}$ ternary system, taking into account the available data on boundary phases, accepted models of interphase boundaries and thermodynamic data used in these models. The end result was a general reduction in the uncertainty of the thermodynamic data values, as well as the position of the phase boundary. The use of modern heuristic optimizers, such as ge- netic algorithms, is crucial for this work, as they are both reliable and do not require any assumptions about the forms of distribution of uncertainty. Based on the phase diagrams of boundary binary systems and a limited number of DTA data from samples of the ternary system using the OriginLab program using the Bayesian statistics method [39], equations describing the surfaces of the primary crystallization of $\mathrm{Ag}_{2} \mathrm{Se}$, $\mathrm{SnSe}_{2}, \mathrm{SnSe}, \mathrm{Ag}_{8} \mathrm{SnSe}_{6}$ and delamination in the $\mathrm{Ag}-\mathrm{Sn}-\mathrm{Se}$ system were obtained. Using these equations, 3D visualization of these surfaces is carried out.

For 3D modeling of the surfaces of monovariant equilibria in the 1-2-3 ternary system, the temperature dependences of the composition are determined as an explicit function $T=f(x, y)$, where the $x$ - atomic fraction of the basis component, say component 1 . Let us assume that $x$ $=X_{1}$, then $y=Y=Y=X_{2} /\left(X_{2}+X_{3}\right)$. This method of analytical 3D modeling of the surfaces of monovariant equilibria of ternary systems was successfully tested on specific systems and described in detail in [41-43]. In this paper, the belowfollowing analytical expressions were obtained for the $\mathrm{Ag}_{2} \mathrm{Se}, \mathrm{SnSe}_{2}, \mathrm{SnSe}, \mathrm{Ag}_{8} \mathrm{SnSe}_{6}$ 
crystallization surfaces and delamination surfaces in the Ag-Sn-Se system.

For the surface of crystallization of $\mathrm{Ag}_{2} \mathrm{Se}$, in the concentration range $X=0.31 \div 0.42$, $Y=0 \div 0.16$ :

$T, \mathrm{~K}=\left[107558-531117(1-X)+875875(1-X)^{2}-\right.$ $\left.-477852(1-X)^{3}\right](1-Y)^{1.06}$.

For the surface of crystallization of $\mathrm{SnSe}$, in the concentration range $X=0.5 \div 0.61$. $Y=0.36 \div 1$. $T, \mathrm{~K}=\left(349+4829 X-6436 X^{2}\right) Y^{0.28}$.

For the surface of crystallization of $\mathrm{SnSe}_{2}$, in the concentration range $X=0.61 \div 0.95$. $Y=0.52 \div 1$.

$T, \mathrm{~K}=\left(-979787,7+7,75995 \cdot 10^{6} X-2,55035 \cdot 10^{7} X^{2}+\right.$ $+4,45533 \cdot 10^{7} X^{3}-4,36243 \cdot 10^{7} X^{4}+2.26954 \cdot 10^{7} X^{5}-$ $\left.4,90063 \cdot 10^{6} X^{6}\right) \mathrm{Y}^{0.35}$.

For the surface of crystallization of $\mathrm{Ag}_{8} \mathrm{SnSe}_{6}$, in the concentration range $X=0.35 \div$ 0.55 . $Y=0.135 \div 0.62$.

$T, \mathrm{~K}=802+2044 Y-6091 Y^{2}+4237 Y^{3}-4049+$ $26685 X-57428 X^{2}+40000 X^{3}$.

For surface immiscibility from $\mathrm{Sn}-\mathrm{Se}$ $(X=0.16 \div 0.49 ; Y=0.33 \div 1)$.
$T, \mathrm{~K}=\left(-1729+37308 X-173477 X^{2}+357612 X^{3}-\right.$ $\left.-275627 X^{4}\right) \mathrm{Y}^{0.38}$.

For surface immiscibility from $\mathrm{Ag}-\mathrm{Se}$ $(X=0.12 \div 0.31 . Y=0 \div 0.33)$.

$T, \mathrm{~K}=\left(-4057+104175 X-753245 X^{2}+\right.$

$\left.+2.40816 \cdot 10^{6} X^{3}-2.87183 \cdot 10^{6} X^{4}\right)(1-Y)$

For surface immiscibility from $\mathrm{Ag}-\mathrm{Se}$ $(X=0.44 \div 0.98 . Y=0 \div 0.53)$.

$T, \mathrm{~K}=\left(-9582+60199 X-127181 X^{2}+119250 X^{3}\right.$ $\left.41950 X^{4}\right)(1-Y)^{0.4}$.

In the equations (4-10): $X=X_{\mathrm{Se}}, \quad Y=$ $X_{\mathrm{Sn}} /\left(X_{\mathrm{Sn}}+X_{\mathrm{Ag}}\right), X_{\mathrm{Ag}}, X_{\mathrm{Sn}}, \mathrm{X}_{\mathrm{Se}}-$ atomic fractions of components in liquid alloys of the $\mathrm{Ag}-\mathrm{Sn}-\mathrm{Se}$ system; the $f(X)$ polynomials are determined on the basis of the liquidus curves of the compounds and the separation curves of double $\mathrm{Ag}-$ $\mathrm{Se}$ and $\mathrm{Sn}-\mathrm{Se}$ boundary systems; The parameters associated with the change in $\mathrm{Y}$ are determined on the basis of a limited number of DTA data from samples of the ternary system and the $\mathrm{Ag}_{2} \mathrm{Se}-\mathrm{SnSe}$ and $\mathrm{Ag}_{2} \mathrm{Se}-\mathrm{SnSe}_{2}$ quasi-binary sections.

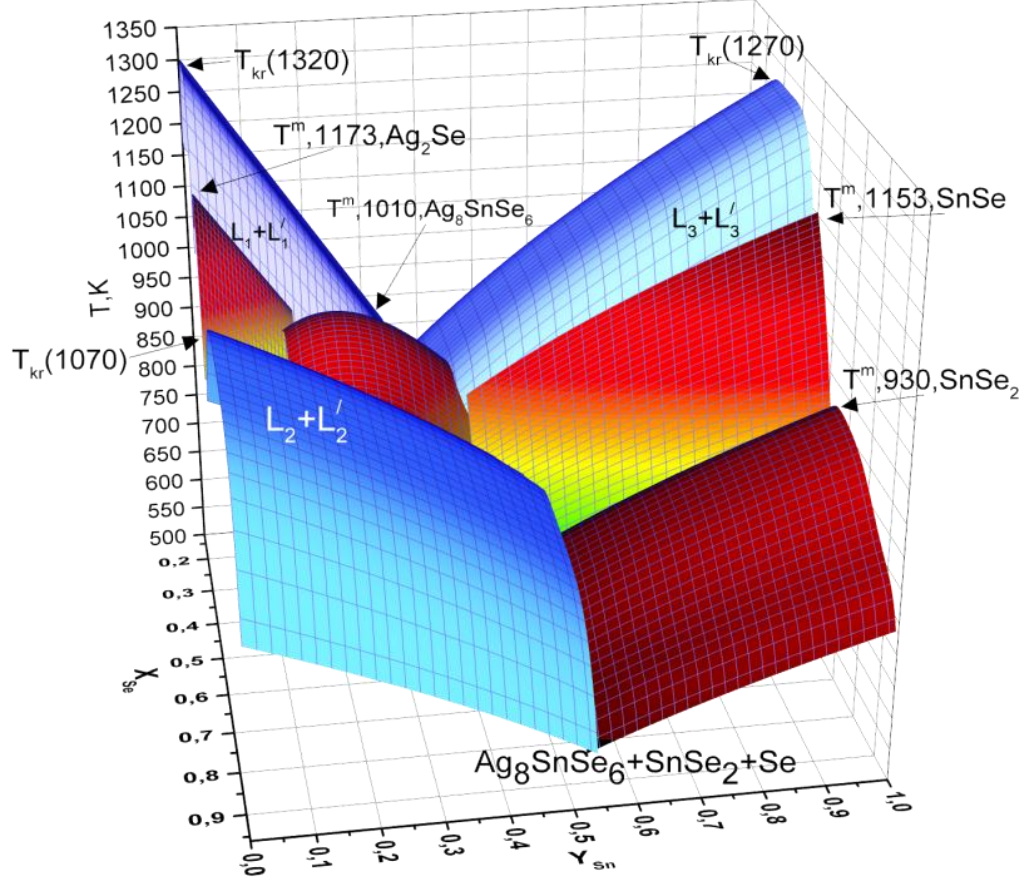

Fig. 7. Multi 3D model of $\mathrm{Ag}_{2} \mathrm{Se}, \mathrm{SnSe}_{2}, \mathrm{SnSe}, \mathrm{Ag}_{8} \mathrm{SnSe}_{6}$ crystallization surfaces and immiscibility surfaces in the $\mathrm{Ag}-\mathrm{Sn}-\mathrm{Se}$ system. 
These analytical expressions with sufficient accuracy explicitly link the liquidus temperatures and the compositions of the components of the ternary system and allowed the task of $3 \mathrm{D}$ visualization of the surfaces of crystallization of compounds and delamination in the system of the Ag-Sn-Se system (Figure 7).

\section{Conclusion}

As a result of the analysis and systematization of literature information, it was revealed that there are reliable data for the phase diagram, the thermodynamic functions of formation and the structure of ternary compounds in the $\mathrm{Ag}-$ $\mathrm{Sn}-\mathrm{Se}$ system, which are used to determine the conditions for the materials synthesis of having mixed ion-electron conductivity in combination with high thermoelectric and optical properties, superconductivity. Modern computer programs are used for the thermodynamic calculation and simulate phase equilibria in the $\mathrm{Ag}-\mathrm{Sn}-\mathrm{Se}$ system. Based on the phase diagrams of the boundary binary systems using a limited number of DTA data, using the computer program OriginLab, analytical expressions were obtained with sufficient accuracy in the explicit form of connecting the liquidus temperatures and the compositions of the components of the ternary system. The 3D visualization problem for $\mathrm{Ag}_{2} \mathrm{Se}, \mathrm{SnSe}_{2}, \mathrm{SnSe}, \mathrm{Ag}_{8} \mathrm{SnSe}_{6}$ crystallization surfaces and delamination surfaces in the $\mathrm{Ag}_{-}$ $\mathrm{Sn}-\mathrm{Se}$ system was solved on the same graph.

\section{References}

1. Li L., Liu Y., Dai J., Hong A., Zeng M., Yan Z., Xu J., Zhang D., Shan D., Liu S., Ren Z., Liu J.M., J. Mater. High thermoelectric performance of superionic argyrodite compound $\mathrm{Ag}_{8} \mathrm{SnSe}_{6}$. J. Mater. Chem. C. 2016. V. 4. P. 5806-5810. DOI: 10.1039/c6tc00810k.

2. Li W., Lin S., Ge B., Yang J., Zhang W., Pei Y. Low sound velocity contributing to the high thermoelectric performance of $\mathrm{Ag}_{8} \mathrm{SnSe}_{6}$. Adv. Sci. 2016. V. 3. P. 1600196-1600200.

3. Semkiv I., Ilchuk H., Pawlowski M., Kusnezh V. $\mathrm{Ag}_{8} \mathrm{SnSe}_{6}$ argyrodite synthesis and optical properties. Opto-Electronics Review. 2017. V. 25. P. 37-41.

4. Cheng K.W., Tsai W.S., Wu Y.H. Photo-enhanced salt-water splitting using or- thorhombic $\mathrm{Ag}_{8} \mathrm{SnS}_{6}$ photoelectrodes in photoelectrochemical cells. J. Power Sour. 2016. V. 317. P. 81-92.

5. Kong-Wei Cheng, Yi Chou. Photoelectrochemical performances of the cubic $\mathrm{AgSnSe} 2$ thin film elec- trodes created using the selenization of thermal evaporated $\mathrm{Ag}-\mathrm{Sn}$ metal precursors. Taiwan Institute Chem. Eng. 2018. P. 1-10. https: doi.org10.1016j.jtice. 2017.11.029

6. Ren Z., Kriener M., Taskin A.A., Sasaki S., Segawa K., Ando Y. Anomalous metallic state above the upper critical field of the conventional threedimensional superconductor $\mathrm{AgSnSe}_{2}$ with strong intrinsic disorder. Phys Rev B. 2013. V. 87. P. 064512.

7. Hull S., Berastegui P., Grippa A. Superionic Conductor $\mathrm{Ag}_{4} \mathrm{Sn}_{3} \mathrm{~S}_{8}$. J. Phys.: Condens. Matter. 2005. V. 17. P. 1067- 1084.

8. Semkiv IV, Lukianec 'B.A., Il'chuk G.A. Energetichna structure of $\beta$-fission crystal $\mathrm{Ag}_{8} \mathrm{SnSe}_{6}$. Z. nano-ta elektronnoï fiziky. 2016. T. 8. № 1. P. 1-5.

9. Gorochov, O., Fitchet R., Flahaut. J. Diagramme de Phase et Proprietes du Systeme $\mathrm{Ag}_{2} \mathrm{Se}-\mathrm{SnSe}_{2}$. C.r. acad. Sci. 1966. V. 263. P. 1422-1424.

10. Ollitrault-Fitchet R., Rivet J., Flahaut J. Description du systeme ternaire $\mathrm{Ag}-\mathrm{Sn}-\mathrm{Se}$. J.LessCommon. Met. 1988. V. 138. P. 241.

11. Pirela M., Velásquez-Velásquez A., Villareal M., Fernández B.J., Vivas L., Sánchez Pérez G. Síntesis y caracterización del material ternario $\mathrm{Ag}_{2} \mathrm{SnSe}_{3}$ dopado con Galio. Revista mexicana de física. 2007. V. 53. No 7. P. 262-264.

12. Dovletov K., Krzhivickaya S.N., Tashliev K. Fazovaya diagramma $\mathrm{Ag}_{2} \mathrm{Se}-\mathrm{SnSe}$. Izv. $\mathrm{AN}$ Turkm. SSR. Ser. fiz.-tekh. i him.-geol. Nauk 1974. No 1. P. 117-118.

13. Moroz V.M., SHCHurok A.I., Mikolajchuk O.G., Byalik M.V. i dr. C Ag-Sn-Se. Osoblivosti strukturi T-h prostoru. Fizika i himiya tverdogo tila. 2003. T. 4. No 3. C. 532-535.

14. Gorochov O. Les composés $\operatorname{Ag}_{8} \mathrm{MX}_{6}(\mathrm{M}=\mathrm{Si}, \mathrm{Ge}$, Sn et $\mathrm{X}=\mathrm{S}, \mathrm{Se}, \mathrm{Te})$. Bull. Soc. Chim. Fr. 1968. P. 2263-2275.

15. Yusibov Yu.A., Alverdiev I.Dzh., Mashadieva L.F., Babanly D.M., Mamedov A.N., Babanly M.B. Experimental Study and 3D Modeling of the Phase Diagram of the Ag-Sn-Se System. Russ. J. Inorg. Chem. 2018. V. 63. Issue 12. P. 16221635. https:doi.org 10.1134 S0036023618120227.

16. Gulay L.D., Olekseyuk I.D., Parasyuk O.V. Crystal structure of $\beta-\mathrm{Ag}_{8} \mathrm{SnSe}_{6}$. J. Alloys Compd. 2002. V. 339. P. 113-117.

17. Wold, A., Brec, R., Structure $\mathrm{NaCl}$ des phases $\mathrm{Ag}_{\mathrm{x}} \mathrm{Sn}_{1-\mathrm{x}} \mathrm{X}(\mathrm{X}=\mathrm{S}$. Se). Mater. Res. Bull. 1976. V. 11. P. 761-766.

18. Yusibov Yu.A., Alverdiev I.Dzh., Ibragimova F.S., Mamedov A.N., Tagiev D.B., Babanly M.B. Study and 3D Modeling of the Phase Diagram of the Ag-Ge-Se System. Russian J. Inorg. Chem. 2017. V. 62. No 9. P. 1223-1233. DOI: 10.1134/S0036023617090182.

19. Ibragimova F.S., Babanly N.B., Tagiev A.N., Tagiev E.R. 3D Modelirovanie poverkhnostei kristilli- 
zatcii $\mathrm{Ag}_{2} \mathrm{Se}$ i $\mathrm{PbSe} v$ troinoi sisteme $\mathrm{Ag}-\mathrm{Pb}-\mathrm{Se}$. Kondensirovannye sredy i mezhfaznye granitcy. 2016. T. 18. № 2. S. 219-224.

20. Ibragimova F.S., Babanly N.B., Tagiev A.N., Tagiev E.R. Fiziko-himicheskii analiz i 3D modelirovanie sistemy $\mathrm{Ag}-\mathrm{Pb}-\mathrm{Te}$. Kondensirovannye sredy i mezhfaznye granitcy. T. 18. № 4. S. 550-557.

21. Shahverdiev A.N., Mekhdiev I.G., Mamedov A.N., Safarov D.S., Hassel E. Teplofizicheskie svojstva i termodinamicheskie funkcii molekulyarnyh i nemolekulyarnyh soedinenij $\mathrm{i}$ ih rastvorov. Baku. Elm. 2013. $313 \mathrm{~s}$.

22. Morachevskij A.G., Sladkov I.B. Termodinamicheskie raschety $\mathrm{V}$ metallurgii. Spravochnik. M.: Metallurgiya, 1985, $137 \mathrm{~s}$.

23. Məmmədov A.N., Bağırov Z.B., Quliyeva S.Ә. Qeyrimolekulyar birləşmələrin termodinamikası. Bakı. Elm. A.N.Mammadov, Z.B.Bagirov, S.A.Guliyeva. Thermodynamics of non-molecular compounds. Baku. Elm. 2006. $192 \mathrm{~s}$.

24. Mamedov A.N. Termodinamika sistem s nemolekulyarnymi soedineniyami. Germaniya. LAMBERT Academic Publishing, 2015,125 p.

25. Mamedov A.N., Alieva D.M., Bagirov Z.B., Mamedov V.S. Raschetnye metody opredeleniya standartnyh termodinamicheskih funkcij soedinenij. Chemical Problems. 2005. No 1. S. 93-96.

26. Moroz M.V., Prokhorenko M.V., Demchenko P.Yu., Reshetnyak O.V., Thermodynamic properties of saturated solid solutions of $\mathrm{Ag}_{7} \mathrm{SnSe}_{5} \mathrm{Br}$ and $\mathrm{Ag}_{8} \mathrm{SnSe}_{6}$ compounds in the $\mathrm{Ag}-\mathrm{Sn}-\mathrm{Se}-\mathrm{Br}$ system measured by the EMF method. J. Chem. Thermodyn. 2017. V. 106. P. 228-231.

27. Moroz M.V. Prokhorenko M.V. Measurement of the thermodynamic properties of saturated solid solutions of compounds in the Ag-Sn-Se system by the EMF method. Russian J. Physical Chemistry. A. 2015. V. 89. Issue 8. P. 1325-1329. https: doi.org10.1134S0036024415080221

28. Fiziko-himicheskie svojstva poluprovodnikovyh veshchestv. Spravochnik. Otv. red. A. V. Novoselova, V. B. Lazarev. M.: Nauka, 1979, 338 s.

29. Baza dannyh. Termicheskie konstanty veshchestv. Iorish V.S. i Yungman V.S. Institut teplofiziki ekstremalnyh sostoyanij RAN. Himicheskij fakultet. MGU, 2006.

30. Wiedemeier H., Pultz G., Gaur U., Wunderlich B. Heat capacity measurements of $\mathrm{SnSe}$ and $\mathrm{SnSe}_{2}$. Thermochimica Acta. 1981. V. 43. P. 297-303. doi:10.1016/0040-6031(81)85187-8.

31. Chemical Thermodynamics of Selenium. In Chemical Thermodynamics 7. Elsevier, 2005.

32. Babanly M.B., Yusibov Yu.A. Elektrohimicheskie metody $\mathrm{v}$ termodinamike neorganicheskih sistem. Baku: Elm, 2011. 306 s.

33. Voronin M.V., Osadchii E.G. Determination of Thermodynamic Properties of Silver Selenide by the Galvanic Cell Method with Solid and Liquid
Electrolytes. Russ. J. Electrochem. 2011. V. 47. P. 420-426.

34. Feng D., Taskinen P., Tesfaye F. Thermodynamic stability of $\mathrm{Ag}_{2} \mathrm{Se}$ from 350 to $500 \mathrm{~K}$ by a solid state galvanic cell. Solid State Ionics. P. 231. V. 1. 2013. DOI: 10.1016/j.ssi.2012.10.013

35. Mammadov A.N., Aliev Z.S., Babanly M.B. Study of the Uncertainty Heterogeneous Phase Equilibria Areas in the Binary YbTe-SnTe System. In: Aliev R., et al. (eds) 13th Intern. Conf. on Theory and Appl. of Fuzzy Systems. ICAFS. 2018. Advances in Intelligent Systems and Computing. 2019. V. 896. Springer, Cham. https:doi.org 10.1007978-3030-04164-9_107.

36. Asadov S.M., Mustafaeva S.N. Mammadov A.N. Thermodynamic assessment of phase diagram and concentration-temperature dependences of properties of solid solutions of the GaS-GaSe system. J.Therm Anal. Calorim. 2018. https: doi.org/10.1007/s10973-018-6967-7.

37. Mamedov A.N., Tagiev E.R., Aliev Z.S., Babanly M.B. Phase Boundaries of the $(\mathrm{YbTe})_{x}(\mathrm{PbTe})_{1-x}$ and $(\mathrm{YbTe})_{x}(\mathrm{SnTe})_{1-x}$ Solid Solutions Series. Inorganic Materials. 2016. V. 52. No. 6. P. 543-545. DOI: $10.1134 / \mathrm{S} 002016851606008 X$.

38. Asadov S.M., Mamedov A.N., Kulieva S.A. Composition- and Temperature-Dependent Thermodynamic Properties of the $\mathrm{Cd}$, Ge\|Se, Te System, Containing $\mathrm{CdSe}_{1-x} \mathrm{Te}_{x}$ Solid Solutions. Inorganic Materials. 2016. V. 52. No. 9. P. 876-885. DOI: 10.1134/S0020168516090016.

39. Thien C. Duong, Robert E. Hackenberg, Alex Landa, Pejman Honarmandi, Anjana Talapatra, Heather M. Volz, Anna Llobet, Alice I. Smith, Graham King, Saurabh Bajaj, Andrei Ruban, Levente Vitos, Patrice E.A. Turchi, Raymundo Arróyave. Revisiting thermodynamics and kinetic diffusivities of uranium-niobium with Bayesian uncertainty analysis. CALPHAD. 2016. V. 55. P. 219-230.

40. Stolen S., Grande T. Chemical thermodynamics of materials: macroscopic and microscopic aspects. John Wiley \& Sons, England. 2004.

41. Mamedov A.N., Salimov Z.E., Mashadiyeva L.F., Babanly M.B. Thermodynamic Calculation and 3D Modeling of the Liquidus and Immiscibility Surfaces of the $\mathrm{Ge}-\mathrm{Cu}-\mathrm{Tl}$ System. Am. Chem. Sci. J. 2016. V. 10. No 2. P. 1-5.

42. Mamedov A.N., Akhmedova N.Ya., Asadov C.M., Babanly N.B., Mamedov E.I. Thermodynamic analysis and defection formation in alloys on the basis of lead selenide containing copper. Chem. Problems. 2019. No. 1. V. 17. P. 16-25.

43. Akhmedova N.Ya., Babanly N.B., Mamedov A.N., Yusibov Yu.Y. Multi-3d modeling of the liquidus and immiscibility surfaces in the $\mathrm{Cu}-\mathrm{Pb}-\mathrm{Te}$ system. Azerb. Chem. Journ. 2019. № 1. P. 59-65. https:doi.org/10.32737/0005-2531-2019-1-59-64. 


\section{СИСТЕМА Ag-Sn-Se: ФАЗОВАЯ ДИАГРАММА, ТЕРМОДИНАМИКА И МОДЕЛИРОВАНИЕ \\ Ф.С.Ибрагимова}

Проведен сравнительный анализ работ по исследованию фазовых равновесий, структур и термодинамических свойств промежуточных фаз тройной системы Ag-Sn-Se. Показано, что в системе образуется два тройных соединения $-\mathrm{Ag}_{8} \mathrm{SnSe}_{6}$ и $\mathrm{AgSnSe}{ }_{2}$, плавящиеся конгруэнтно при 1015 К и инконгруэнтно при 860 К, соответственно. Рекомендованы наиболее достоверные данные для энтальпии, энтропии, свободной энергии образования и теплоемкостей $\mathrm{AgSnSe}_{2}$ и аргиродитной фазы $\mathrm{Ag}_{8} \mathrm{SnSe}_{6}$. Термодинамические функции смешения жидких растворов аппроксимированы в рамках асимметрического варианта модели регулярных растворов. Для определения границ расслоения жидких сплавов использована функция внутренней термодинамической стабильности гомогенной фазы. С помощью программы OriginLab2018 проведена мульти 3D визуализация поверхностей кристаллизации $\mathrm{Ag}_{2} \mathrm{Se}, \mathrm{SnSe}_{2}, \mathrm{SnSe}, \mathrm{Ag}_{8} \mathrm{SnSe}_{6}$ и поверхностей расслаивания в системе $\mathrm{Ag}-\mathrm{Sn}-\mathrm{Se}$.

Ключевые слова: система медь-свинец-теллур, фазовая диаграмма, поверхность ликвидуса, 3D моделирование.

\section{Ag-Sn-Se SISTEMI: FAZA DİAQRAMI, TERMODINAMIKA Və MODELLəŞMə}

\section{F.S.İbrahimova}

Ag-Sn-Se üçlü sisteminin faza diaqramının, aralıq fazalarının strukturlarının və termodinamik xassələrinin öyrənilməsi üzrə işlərin müqayisəli təhlili aparılmışdır. Sistemdə $\mathrm{Ag}_{8} \mathrm{SnSe}_{6}$ və $\mathrm{AgSnSe}_{2}$ üçlü birləşmərinin əmələ gəlməsi, onların müvafiq olaraq $1015 \mathrm{~K}$-də parçalanmadan əriməsi və $860 \mathrm{~K}$-də parçalanaraq əriməsi müəyyən edilmişdir. $\mathrm{AgSnSe}_{2}$ və argirodit $\mathrm{Ag}_{8} \mathrm{SnSe}_{6}$ birləşmələrinin əmələgəlmə enthalpiya, entropiya, sərbəst enerjiləri və istilik tutumları üçün ən etibarlı məlumatlar təklif olunur. Maye ərintilərin qarışma termodinamik funksiyaları müntəzəm məhlullar modelinin asimmetrik versiyası əsasında ifadə edilir. Maye ərintilərin təbəqələşmə sərhədlərini müəyyən etmək üçün homogen fazanın daxili termodinamik sabitlik funksiyasından istifadə edilmişdir. OriginLab proqramın köməyi ilə Ag-Sn-Se sistemindəki $\mathrm{Ag}_{2} \mathrm{Se}, \mathrm{SnSe}_{2}, \mathrm{SnSe}, \mathrm{Ag}_{8} \mathrm{SnSe}_{6}$ birləşmələrinin kristallaşma səthləri və maye ərintilərinin təbəqələşmə səthlərinin çoxsahəli 3D görüntüsü verilmişdir.

Açar sözlor: mis-qurğuşun-tellur sistemi, faza diaqramı, lividus səthi, 3D modelloşdirilmə. 